Editorial

\title{
Sport, Spirituality, and Religion: New Intersections and Global Challenges
}

\section{Tracy J. Trothen}

School of Religion and School of Rehabilitation Therapy, Queen's University, Kingston, ON K7L 3N6, Canada; trothent@queensu.ca

Received: 12 August 2019; Accepted: 3 September 2019; Published: 23 September 2019

Abstract: Sport, religion, and spirituality intersect in diverse ways. As the body of interdisciplinary scholarly work addressing these intersections increases, more questions and insights are being generated, as evidenced in this collection. Five themes that arise in this Special Issue of Religions are identified and explored. Examples from each article are used to develop these themes. To whet the reader's appetite, thought-provoking reflections are offered in this introduction to "Sport, Spirituality, and Religion: New Intersections and Global Challenges."

Keywords: sport; religion; spirituality; Christianity; social justice; hope; spiritual emotions

\section{Introduction}

Sport, religion, and spirituality intersect in diverse ways. Scholarship exploring the intersections of sport, spirituality and religion has been growing at a fast pace in recent years (Watson and Parker 2013). This growth may be partly explained by a move away from organized religion towards secularism. Not all countries are seeing a decline of organized religion but such a decline is becoming increasingly evident in parts of the United States and the United Kingdom, the contexts for most of the essays in this Special Issue of Religions.

As the body of interdisciplinary scholarly work addressing these intersections increases, more questions and insights are being generated, as evidenced in this collection. The scholars who have contributed articles to this Special Issue include experts in: sports studies; health, human performance and recreation; religion; Christian theology; philosophy; Judaism; rehabilitation therapy; and history. While most of the essays in this issue employ theoretical approaches, Robert Ellis, Terry Shoemaker, Andrew Parker and Mark Oliver also use social scientific research methods. The authors' diverse expertise and research methods yield fascinating new questions and postulations that expand this field of inquiry.

I identify and explore five themes that arise in this Special Issue of Religions regarding the intersections of sport, religion, and spirituality: the capacity of sport to achieve ends similar to those ends achieved by organized religions; connections or parallels between sport and Christianity; relationality and power; hope and social justice; the capacity of sport to inspire "spiritual" emotions; and the interpretation or meaning attached to subjective experiences that might seem spiritual or religious in sport. In the hopes of whetting your appetite to read on, I attempt to offer some thought-provoking musings in this introduction to "Sport, Spirituality, and Religion: New Intersections and Global Challenges."

\subsection{Sports Can Achieve Similar Ends to Religion}

Eric Bain-Selbo and Gregory Sapp do an excellent job, in their 2016 book Understanding Sport as a Religious Phenomenon-An Introduction, establishing that sports have the capacity to achieve ends similar to those achieved by organized religions (Bain-Selbo and Sapp 2016). Using Ninian Smart's 
seven dimensions of a religion (Smart 1996), Bain-Selbo and Sapp show that sport can satisfy each of these dimensions. They do not seek to prove that sport actually is a religion but, as Rebecca Alpert puts it in her article concerning baseball's Babe Ruth, "We need not argue whether sports are religions to assert that they can achieve the same ends as systems traditionally defined as religions." While previous publications engage Smart's theory to demonstrate that sport can satisfy the dimensions of a religion (ex. Price 2006; Alpert 2015), four authors in this Special Issue examine new aspects and moments of this intersection adding weight to the claim that sport can achieve the same ends as organized religions.

In her consideration of baseball's Babe Ruth (1895-1948) as a mythic figure (e.g., one of Smart's seven dimensions), Alpert makes the case that Babe Ruth is best understood as a religious icon. Building on the dual strands of Ruth's Roman Catholic religious identity and The United States' response to baseball in the 1920s to the 1950s, Alpert illuminates the function of Babe Ruth as a religious icon in the U.S. American civil religion of baseball. Alpert makes a strong case for baseball being a civil religion, exemplifying the virtues and values of mainstream United States in ways similar to an organized religion. Implications of Ruth's iconic status have been the sacralising of associated objects (e.g., Babe Ruth's team jerseys and baseball equipment) and associated baseball spaces.

Theologian Robert Ellis takes the scope of this Special Issue beyond the United States (as do Andrew Parker and Mark Oliver in their compelling article on sports chaplaincy, and Brett Potter who explores the growing sport phenomenon of parkour) in his article "Sporting space, sacred space: a theology of sporting place." Ellis explores an aspect of Smart's seventh dimension of a religion-materiality - in his consideration of special places in sport. Drawing on United Kingdom examples, Ellis takes us on a tour of special religious and sport spaces including Iona and the Holy Island of Lindisfarne, Durham Cathedral, and the Millennium Stadium. Acknowledging the moral ambiguity of both sport and religion, Ellis posits that the flawed quality of sport and religion does not rule out the "specialness" of some religious spaces and sporting spaces. Ellis concludes "that insofar as sport can be a vehicle for encounter with the divine, it is in no small part because of the part played by its special places in mediating such experiences."

Potter, too, considers the relationship between religion, spirituality, and space in his examination of the global sport of parkour, which he describes as running or moving efficiently though the environments of the globalized city, in "Tracing the Landscape: Re-enchantment, Play, and Spirituality in Parkour." Potter sees parkour and its offshoot, free-running, as "like" a religion insofar as parkour exhibits aspects of religion such as pilgrimage, and the promotion of virtues and pillars that are similar to some of those in Buddhism and Hinduism.

Bain-Selbo suggests that sport can function similarly to religion by providing the possibility of so-called spiritual or religious emotions. In his article, "Affect Theory, Religion, and Sport," Bain-Selbo builds the argument that affect generated in sport may be the same as affect generated in religion. Using Donovan O. Schaefer's understanding of affects as "the flow of forces through bodies outside of, prior to, or underneath language," Bain-Selbo reflects on the possible meanings of affect in sport and the need for critical interpretation of these affect experiences. He builds a strong case for affects as ends in religions and similarly in sport. The fact that many people who experience powerful affect in sport do not name these experiences as spiritual or religious is likely at least partly due to contextual labelling. Even though the same words may not be used to describe strong emotions experienced in religion and in sport, Bain-Selbo suggests that religion and sport can achieve similar or even the same strong affects.

In his essay "Deconversion, Sport, and Rehabilitative Hope," Terry Shoemaker presents findings from his qualitative and ethnographic research on post-evangelical followers in the northern United States portion of the "Bible Belt." No questions specific to sport were asked in the 65 interviews but $15 \%$ of the respondents referred to sport in reflecting on their experiences of leaving a conservative evangelical church. Shoemaker's research suggests that sport may have the capacity to fulfil the ends of relationality and hope sometimes more effectively than religion. He concludes that sport 
intersects-often in constructive ways-with deconversion from conservative evangelical Christian churches for some people.

These essays together make a strong case for sport offering many of the same ends that may be sought in organized religions. The fact that these authors chose their topics for this Special Issue independently may suggest that this theme is attracting growing interest and conviction.

\subsection{Connections or Parallels between Sport and Christianity}

Alpert, Ellis, Shoemaker, and Andrew Meyer all draw connections or parallels between sport and Christianity. While this theme is not new in scholarship regarding religion and sport, the points of intersection identified are new or the authors offer new insights.

Alpert's exploration of Babe Ruth emphasizes Ruth's role in bringing Roman Catholicism to mainstream America. Alpert helps the reader to understand how Babe Ruth exemplified aspects of the Roman Catholic religious commitment to social justice, particularly for children and the poor. She surmises that Ruth's huge successes on the baseball diamond gave more power and perhaps mystique to his Roman Catholic identity. Alpert provides a number or rich examples that illustrate this connection, personified in Babe Ruth, between baseball and Roman Catholicism at a time when the reputation of baseball was precarious.

Meyer uses the biblical source to shed light on another high-profile athlete, cyclist Lance Armstrong, and his dramatic fall from grace. Meyer reflects on the possible meaning of Armstrong's doping scandal. Using the Isaiah narratives, Meyer proposes that this biblical source can reveal redemptive meaning in Armstrong's narrative of prelapsarian glory followed by a fall of almost biblical proportions. Through being forced into exile, Meyer surmises that Lance may have gained the possibility of redemption not as an elite cyclist but, more importantly, as a person. This exploration of a parallel between the Isaiah narratives and Lance Armstrong's narrative helps the reader to see both Armstrong and this biblical story from another perspective.

Shoemaker looks at another way in which sport intersects with Christianity, inviting us to consider the relationship of sport to the deconversion experiences of some who have left conservative Christian evangelical churches. He predicts that further research may support the role of sport in providing alternative identities, relationships, and rehabilitative hope for many who decide that their evangelical Christian community no longer fits with their identities, convictions and desires.

Jeffrey Scholes examines the relationship between racialization and reactions to displays of Christian faith on the gridiron, in his ground-breaking article "Pray the White Way: Religion Expression in the NFL in Black and White." Scholes makes the reader pause and ask critical questions regarding how we evaluate some theological interpretations as superior to others. In this re-consideration he finds that the types of theologies that are judged more harshly are African American theologies. Scholes builds a persuasive case. This article will change how you see athletes, and especially black National Football League (NFL) players, who attribute a win to God.

Through engagement with Christian theological concepts including incarnation, sacrament, and Trinity, Ellis suggests that there are important similarities between the qualities and experiences of Christian and other religious special places and sporting special places. In so doing, he adds weight to arguments against binary approaches to the sacred and the profane. From a Christian theological perspective, Ellis proposes that God may mediate "saving presence and grace" in any place, including sports' spaces.

These papers develop new angles and even planes in the intersection of Christianity and sport. The authors give us new lenses through which to see sports and athletes in relation to Christianity.

\subsection{Hope and Social Justice}

All the authors in this Special Issue of Religions address hope and most connect hope to social justice. The authors see both sport and religion as having the ambiguous potential both to challenge and to reinforce socially normative patterns of power, privilege, and marginalization. 
Sport researchers Parker and Oliver explore new ground in "Safeguarding, Chaplaincy and English Professional Football." In a qualitative study, Parker and Oliver investigated the role of sports chaplains in safeguarding the welfare of vulnerable elite youth footballers in England. This safeguarding can be understood as offering hope for the well-being of vulnerable players, and thus promoting social justice in the English football context. Their research suggests that the perception of the chaplain as removed from the team and safe, may give the chaplains protective potential; sports chaplains seem to be particularly trusted figures and so have a greater opportunity to protect these young footballers from abuse. As Parker and Oliver point out, chaplains have a unique role in elite youth football in that they are able to prioritize the well-being of the players over their sports performance. The authors implicitly suggest that religiously informed values and behaviors can be more person-oriented and protective than elite sports values.

Scholes addresses social justice in the NFL in his critical analysis of elite sport and of normative white Christian discourse in the United States. Scholes' important consideration of racialized evaluations of religious expression in professional American football gives one pause. Is the denigration of providential and hope-filled theological declarations in sport (e.g., God decided that our team should win tonight) a social and theological justice issue? I am convinced now that it is. The question of whether God cares about football connects in no small way to big political and economic questions. When Scholes quotes journalist David French as saying "to get God out of football, the anti-religious crowd would need to get the football players out of football," as a Canadian I immediately thought of Quebec's recent secularism law, Bill 21, which forbids religious symbols in the public sector (passed into law on 16 June 2019). Legislated or rule-based attempts to address religious and secular diversity by denying such expression arguably denies the diversity of human faith commitments and world views. At the same time, philosopher Randolph Feezell's point that faith expressions ought to be held fallibly in a pluralistic context, must be held in tension with public faith expressions (Feezell 2013). Scholes' article is a strong reminder of the insidiousness of racism and the importance of faith fallibility. It can be easy to judge players who seem to declare their faith as infallible but what about the critics who assume that their judgements regarding players' faith expressions are infallible?

Hope is a significant theme in Meyer's article. Meyer sees Lance Armstrong as a complicated sports icon, fallen hero, and potential symbol of the promised land. Meyer is interested in the ambiguity represented by Armstrong in his "Livestrong" charitable work and his advocacy for those battling cancer as he himself did. For Meyer, Armstrong represents human fallibility and the redemptive possibility that is promised by religions such as Christianity. Meyers concludes, "there is hope in despair" and, more profoundly and even controversially, it may be that true hope requires despair. For those who ask where the social justice is in Lance Armstrong's gradual emergence from exile, you will find Meyer's article thought provoking.

Shoemaker's article is more immediately about hope than social justice. However, if an aspect of social justice is the re-claiming of one's faith and sport identities and values, then this article is also about social justice for those who experience marginalization because of what they believe. In his examination of post-conservative Protestants including evangelicals, fundamentalists, and Pentecostal followers, Shoemaker argues that "sport can offer a rehabilitative hope for familial fracturing caused by religious deconversion, a spatial opportunity in a restrictive milieu to expand one's social network, and a space to align with contemporary social issues." Shoemaker's research shows that sporting interactions can be disruptive to faith identities by interacting with others with different racial, sexual, and faith identities. In other words, sport experiences can contribute to a choice to deconvert. But sport can also assist in the healing of relational, including familial, breaks that are caused by "religious shifts away from evangelicalism." In the study, sport was also identified as a place in which people who experienced deconversion could connect with others who share similar emergent values. Sport may provide rehabilitative hope in the work of deconversion and self-discovery.

In linking American civil religion and Babe Ruth's Catholic faith identity, Alpert shows that Ruth was an icon of hope for succeeding against the social odds, especially in the context of the two world 
wars and the Depression of the 1930s. People from all social classes could identify with him in some way. His Catholic faith was potentially marginalizing but he embraced it. Alpert emphasizes that it was not his confessions of bad behavior and apologies as much as his sometimes-overlooked championing of those on the margins, including children and the poor, that may have been the clearest expression of his faith. Alpert shows how Babe Ruth, religious icon and saviour, helped to illuminate the social justice aspect of Roman Catholicism and the persistent possibility of hope for the downtrodden.

Ellis also addresses hope as it is associated with special places in religions and sport. He describes an almost palpable sense of divine love and awe that is generated in some sport places that can help to bring us a strong sense of spiritual presence. This sense of awe and "wow" is not mitigated by human moral fallibility. Rather, as Ellis persuasively argues, the hope that these special places can inspire may be more sacramental in nature, an unfathomable generous unveiling of the divine. Ellis invites us to be critical but open to holy experiences in special places that are not necessarily religious places. His article makes me wonder how the emotional and spiritual "wow" factor may be related to good (or bad) works.

Potter shows us that parkour can be a global way to raise the valuing of the embodied person and the environment, and specifically the urban environment as it connects to human spirituality. He suggests the concept of religious poesis for understanding the transformation of the body through engagement with the urban landscape. Potter concludes that parkour and free-running provide us with a way forward towards ecojustice: "Perhaps parkour, with its emphasis on embodied experience of the landscape, can help transform this [urban] desert into an oasis. An 'enchanted' view of not only nature, but the urban landscape itself as full of potential for beauty and grace, could perhaps be the basis for a renewed ecological consciousness." As Potter points out, social justice must include the creative rehabilitation of the earth.

Hope is often explicitly linked to social justice in the above essays. The authors agree that hope is not restricted to religion but is found by many, and sometimes more easily, in sport than in religion. As these authors demonstrate, sport and religion are ambiguous. They share the capacity for generating hope and modeling social justice, and they share the capacity for abuse and oppression.

\subsection{Sport and (Spiritual?) Strong Emotions}

This theme is perhaps the least obvious and most limited in terms of how much is said directly concerning emotions in the articles. Yet, I think emotions are an important theme since they are mentioned often, even if briefly or implicitly, in the articles by Alpert, Ellis, Potter, Scholes, Meyer, Shoemaker, and Bain-Selbo.

Alpert demonstrates that many of Babe Ruth's followers made him into a religious icon and, in the same way as a religious icon, Ruth redeemed baseball's "awe-inspiring power and beauty" from revelations of gambling and violence. Ellis writes about the "wow" moment of encountering special sport and religious places. In his exploration of parkour and free-running, Potter also makes implicit reference to the "wow" factor of the "enchanted" urban landscape "as full of potential for beauty and grace." Scholes looks at religious displays on the gridiron; no one would argue that these displays are not partly fueled by strong emotions of ecstasy, awe, hope, and gratitude. Meyer's essay on Lance Armstrong is laced with strong emotions including despair, suffering, and hope. Shoemaker distills three types of rehabilitative hope in sport for people who are experiencing the emotional stress of deconversion. What is the meaning of these strong emotions? Why are strong emotions so consistently associated with the intersection of sport, spirituality, and religion?

Bain-Selbo helps us to probe these questions about emotions, religion, and sport by engaging affect theory. His contention that there are no irreducibly religious emotions caused me to ponder further the distinction between religious and spiritual in regard to affects. I agree that "the physiological changes (the felt experience) of the religious experience are in fact religious to the extent that they are interpreted religiously - they are not intrinsically religious." And I would take Bain-Selbo's argument a step further: I wonder if some of these emotional responses might be considered "intrinsically 
spiritual." By intrinsic, I mean that these emotional responses might possess an irreducible spiritual quality that is not restricted to any particular context, including religions (Pargament 2013b).

I have written about sport as a place where some people discover the sacred, building on research by psychologist Kenneth I. Pargament and his colleagues (Trothen 2018). I cannot do their work justice in this very brief reflection but I will summarize a few key points and leave you, the reader, to investigate their findings more closely should you choose. Pargament and his colleagues have found that people can discover the sacred in any number of life experiences and/or objects. They also have found that these experiences of the sacred cannot be fully explained by or reduced to psychological needs, or desires, or any other motivation. In his research, Pargament observed six implications for one's everyday life stemming from the discovery of the sacred (Pargament 2013a; Pargament et al. 2017) and that the experience of discovering the sacred has at least three qualities: transcendence, ultimacy, and boundlessness (Pargament 2007). One of the implications of discovering the sacred is the experience of strong emotions that may be considered spiritual emotions (Pargament 2013a) when they occur conjointly with the other five implications and the three or more spiritual qualities. It may well be that some people discover the sacred in sport and experience emotions that can be understood as (irreducibly?) spiritual.

I suspect that these questions about strong emotions, spirituality, religion, and sport will attract increasing attention. The emotional intensity in sport can be expressed in life-enhancing as well as destructive ways, as we have seen in large fan crowds. If these emotions have a spiritual dimension for at least some people, we need to better understand the relevance and meaning of this spiritual dimension if we want to assist people to express these emotions constructively (Trothen 2018).

\subsection{The Interpretation of Meaning: Is Everything Spiritual or Religious Because I Say So?}

The understanding of strong emotions in sport is part of a bigger question: how do we interpret the meaning and value of sport and religion, and/or spirituality, when they intersect? The articles by Bain-Selbo, Ellis, Potter, Scholes, and Parker and Oliver, suggest this question.

Bain-Selbo repeats Wayne Proudfoot's caution that "we must be careful not to protect claims of affect and religion from rational inquiry." We should not accept that any strong emotion experienced in sport (or in any context) is a religious affect experience just on someone's say-so. We need more critical interpretation. Bain-Selbo pushes this caution further and asks if there are no sui generis religious affect experiences, then is it not possible to have emotional experiences in sport that are similar to or the same as emotional experiences in religion? If so, then it may be that those who have bought into a false dichotomy between the religious and the secular have misapprehended authentic religious or spiritual experiences in sport. As he puts is, "If the participants in the sporting event had a different understanding of what religion is or what a spiritual experience is, perhaps they more likely would apply these terms to describe their experiences and, thus, those experiences legitimately could be considered religious or spiritual." In raising the possibility that some people have what have been understood as religious or spiritual experiences in sport, Bain-Selbo points to a looming question: how well do we understand or even recognize religion or spirituality?

Ellis and Potter also urge us to question a sharp distinction between the so-called sacred and the so-called profane, in their respective explorations of special places in sport and religion, and the parkour participant in relation to the urban landscape. Cautioning against an assumption that any and all places are sacred or spiritual, Ellis nonetheless argues that a place can be sacred or spiritual. He rejects a pantheistic understanding of these special places, arguing instead that while God can mediate love and other divine actions through special places, we need to critically explore the meaning of our experiences in these places. Ellis proposes theological concepts that can assist in this critical evaluation and discernment of spirituality in particular places. Ellis concludes that "[w]e should resist any tendency to separate 'sacred space' too rigorously and find a balance between the rejection of the notion of sacred space and the banal affirmation that every space is always sacred." 
Potter echoes Ellis by challenging the idea that only particular spaces are associated with the spiritual: "This tendency to separate out the sacred and the secular is precisely what is called into question by emergent practices such as parkour and free-running." Potter sees parkour as reconfiguring (urban) space by not confining "enchantment" to "'sacred' spaces like the stadium, gallery, or church." So, is enchantment the same as spirituality? How should we understand the ability of parkour to reconfigure space and defy any distinction between the sacred and the secular? How is this proposal different from Ellis'? Ellis puts an emphasis on divine revelation and human response whereas Potter may see human agency, expressed in parkour or free-running, as mainly or solely responsible for the reconfiguration of urban space into sacred space. The question of how we interpret and discern sacredness comes to the fore in these two papers. I encourage you to read both and see what you think.

Scholes, too, raises the question of interpretation in looking at providential faith convictions expressed by African American NFL players. Is God's hand in the winning touchdown? Is a completed pass providential, a manifestation of the sacred? Who gets to decide which faith interpretations are acceptable? How do we promote fallible religious claims in the public sphere without also promoting racist evaluations of players' religious beliefs? Scholes reminds us that our own judgements of religious displays can manifest promote a sort of infallibility and arrogance.

The question of what makes a sport experience spiritual or religious also emerges implicitly in Parker and Oliver's article. Young footballers may perceive chaplains as invested not in their sport performance primarily but in their well-being. The chaplains seem not to be interpreted as being owned by the team but as being accountable and committed to their faith. Thus, (I would add) rightly or wrongly, the chaplains may be seen as safer and more trustworthy. Again, a key question concerns how we interpret the meaning of religious or spiritual and where we discern religious or spiritual qualities.

\section{Concluding Remarks and Invitation to This Special Issue}

I have made a mere beginning in distilling some of the significant themes raised in this Special Issue of Religions on "Sport, Spirituality, and Religion: New Intersections and Global Challenges" and I urge the reader to look for additional themes. These essays help us to understand the complexities of the intersection of sport, spirituality, and religion. While these essays do not explicitly venture outside of the United States and the United Kingdom, with the notable exception of Potter's intriguing article on parkour, I suspect that many of these themes and questions could be extended into additional cultural contexts. I urge you to consider how these articles might generate further insights and direct engagement with more diverse contexts. I am sure that you will find yourself stimulated and challenged by this impressive collection. Enjoy!

Funding: This research received no external funding.

Conflicts of Interest: The author declares no conflict of interest.

\section{References}

Alpert, Rebecca T. 2015. Religion and Sports: An Introduction and Case Studies. New York: Columbia University Press. Bain-Selbo, Eric, and Gregory D. Sapp. 2016. Understanding Sport as a Religious Phenomenon-An Introduction. London: Bloomsbury Academic.

Feezell, Randolph. 2013. Sport, Religious Belief, and Religious Diversity. Journal of the Philosophy of Sport 40: 135-62. [CrossRef]

Pargament, Kenneth I. 2007. Spiritually Integrated Psychotherapy: Understanding and Addressing the Sacred. New York: Guilford.

Pargament, Kenneth I. 2013a. Searching for the sacred: Toward a non-reductionist non-reductionist theory of spirituality. In APA Handbooks in Psychology, Religion, and Spirituality: Context, Theory, and Research. Edited by Kenneth I. Pargament, Julie J. Exline and James W. Jones. Washington: American Psychological Association, vol. 1, pp. 257-74. 
Pargament, Kenneth I. 2013b. Spirituality as an irreducible human motivation and process. The International Journal for the Psychology of Religion 23: 271-81. [CrossRef]

Pargament, Kenneth I., Doug Oman, Julie Pomerleau, and Annette Mahoney. 2017. Some contributions of a psychological approach to the study of the sacred. Religion 47: 718-44. [CrossRef]

Price, Joseph L. 2006. Rounding the Bases: Baseball and Religion in America. Macon: Mercer University Press.

Smart, Ninian. 1996. Dimensions of the Sacred: An Anatomy of the World's Beliefs. Berkeley: University of California Press.

Trothen, Tracy J. 2018. Spirituality, Sport, and Doping: More Than Just a Game. Springer Briefs Sport and Religion Series; Basel: Springer International Publishing.

Watson, Nick J., and Andrew Parker. 2013. Sports and Christianity: Mapping the Field. In Sports and Christianity: Historical and Contemporary Perspectives. Edited by Nick J. Watson and Andrew Parker. New York: Routledge, pp. 9-88.

(C) 2019 by the author. Licensee MDPI, Basel, Switzerland. This article is an open access article distributed under the terms and conditions of the Creative Commons Attribution (CC BY) license (http://creativecommons.org/licenses/by/4.0/). 